\title{
ASSESSMENT OF THE IMPACT OF THE INTERNATIONAL TRADE IN AGRICULTURAL PRODUCTS ON THE EU ECONOMIC GROWTH
}

\author{
Rita Remeikiene, Zoltan Rozsa, Ligita Gaspareniene, Jan Pěnčík
}

\section{Introduction}

According to Shah (2015), economic growth is a primary and crucial aim of national and regional economies. International trade, based on exploitation of the benefits of comparative advantage, is treated as one of the key determinants of a sustainable economic growth. Being a structural part of the overall international trade, the international trade in agricultural products is an important engine of economic progress.

Despite the abundance of the scientific studies proving the positive links between international trade and national and/or regional economic growth (Sun \& Heshmati, 2010; Adhikary, 2010; Busse \& Koniger, 2012; FetahiVehapia \& Sadikub, 2015; Vojtovic, 2016; Kljucnikov \& Popesko, 2017; Weng et al., 2017, Simionescu et al., 2017 etc.), the international trade in agricultural products thus far has not earned the sufficient scientific attention. As it was noted by Josling et al. (2010), the studies of the international trade in agricultural products and agri-food is a relatively new and specific area of economic research. Minding the results of some scientific studies indicating significant structural differences in economic growth between low, lower-middle and upper-income countries (Verter \& Bečvářová, 2016) as well as the projections of the global population and food demand future trends (with reference to the data of the Food and Agriculture Organization of the United Nations (2009), the number of the global population will have exceeded 9 billion by 2050, which, in turn, will determine the demand for cereals to reach 3 billion tones by the same year, up from today's nearly 2.1 billion tonnes), the analysis of the impact of the international trade in agricultural products on economic growth is extremely relevant.

Although some scientific sources provide the empirical evidence of the positive links between the international trade in agricultural products and economic growth (Henneberry \& Curry, 2010; Erokhin et al., 2014; Hidayatie, 2014; Verter, 2015; Verter \& Bečvářová, 2016, etc.), the results of some other studies indicate the inverse (Josling et al., 2010; Shah et al., 2015; Yang et al., 2017, etc.) relationship, which calls for more comprehensive research in this area.

The purpose of this article is to assess the impact of the international trade in agricultural products on economic growth of EU 28. For fulfilment of the defined purpose, the following objectives have been raised: 1) to reveal the factors determining the specificity of the international trade in agricultural products in terms of the impact on economic growth; 2 ) to select and introduce the methodology of the research; 3 ) to provide the results of the empirical research on the impact of the international trade in agricultural products on the EU economic growth.

The assessment of the impact of the international trade in agricultural products on the EU economic growth has revealed that the international trade in agricultural products mainly affects the EU economy through GDP, the self-employed, employment in the agricultural sector, subsidies and other transfers, labour force gender, and total governmental final consumption expenditure. The estimations have disclosed that while analysing the impact of the international trade in agricultural products on economic growth, there is no necessity to research export and import volumes in separate as agricultural export and import show nearly the same (only with insignificant value differences) determinants of economic growth promotion. The originality of the research manifests through identification of the strongest EU agricultural sections in terms of international trade, which, in turn, may help 


\section{Ekonomie}

economic growth policy makers concentrate on the promotion of the efficiency of the strongest agricultural sections.

The methods of the research include systematic and comparative literature, statistical mathematical calculations.

\section{Specificity of the International Trade in Agricultural Products}

Although scientific literature is rich in the studies on the links between international trade and economic growth, the relationship between the international trade in agricultural products and economic growth should be discussed as a separate issue with consideration of its specificity.
As late as agricultural export accounted for 75 percent of the total exports of the USA, trade in agricultural products and agri-foods "has been a significant share of the total commerce" (Josling, 2010, p. 425). Despite the fact that the international trade in agricultural products and agri-foods is a structural part of the overall international trade, it should not be overlooked that the international trade in agricultural products and agri-foods is characterized by slightly different features than, for instance, the international trade in industrial products. The analysis of the scientific literature has allowed to identify the factors determining the specificity of the international trade in agricultural products (see Tab. 1).

\begin{tabular}{|c|c|c|}
\hline $\begin{array}{l}\text { The fa } \\
\text { produc }\end{array}$ & \multicolumn{2}{|c|}{$\begin{array}{l}\text { The factors determining the specificity of the international trade in agricultural } \\
\text { products }\end{array}$} \\
\hline Factor & International trade in agricultural products & Author(s), year \\
\hline Political attitudes & $\begin{array}{l}\text { Placing of values on the maintenance of family } \\
\text { farm systems; development strategies for rural } \\
\text { areas }\end{array}$ & $\begin{array}{l}\text { Zeeuw, 1997; Kay, 2009; } \\
\text { Lenihan et al., 2009; } \\
\text { Josling et al., 2010, etc. }\end{array}$ \\
\hline Protectionism & $\begin{array}{l}\text { A large number of countries, including EU, are } \\
\text { inclined to protect their agricultural sector from } \\
\text { low cost imports }\end{array}$ & $\begin{array}{l}\text { McCally \& Nash, 2007; } \\
\text { Josling et al., 2010; Laborde } \\
\text { \& Martin, 2012; Markovič \& } \\
\text { Markovič, 2014, etc. }\end{array}$ \\
\hline $\begin{array}{l}\text { Ignored rules } \\
\text { of supply } \\
\text { and demand }\end{array}$ & $\begin{array}{l}\text { Ignorance of the rules of supply and demand } \\
\text { leads to overproduction and surplus of } \\
\text { agricultural products which are either destroyed } \\
\text { or dumped on developing countries }\end{array}$ & $\begin{array}{l}\text { McCally \& Nash, 2007; } \\
\text { Laborde \& Martin, 2012; } \\
\text { Verter \& Bečvářová, 2014, } \\
\text { etc. }\end{array}$ \\
\hline $\begin{array}{l}\text { Conditions of } \\
\text { competition }\end{array}$ & Distorted conditions of free market competition & $\begin{array}{l}\text { Josling et al., 2013; } \\
\text { Franič \& Mikuš, } 2013 \\
\end{array}$ \\
\hline $\begin{array}{l}\text { Closeness } \\
\text { of the sector }\end{array}$ & $\begin{array}{l}\text { Countries with high-cost agriculture are inclined } \\
\text { to restrict the amounts of agricultural import } \\
\end{array}$ & $\begin{array}{l}\text { Wen et al., 2013; Cai \& } \\
\text { Song, 2016; Viju et al., } 2017\end{array}$ \\
\hline $\begin{array}{l}\text { High-cost } \\
\text { production }\end{array}$ & $\begin{array}{l}\text { High cost agricultural production leads to } \\
\text { inadequate, imbalanced and diversified trade }\end{array}$ & $\begin{array}{l}\text { Wen et al., 2013; } \\
\text { Cai \& Song, } 2016 \\
\end{array}$ \\
\hline $\begin{array}{l}\text { Incomplete } \\
\text { international } \\
\text { agricultural price } \\
\text { transmission }\end{array}$ & $\begin{array}{l}\text { It mitigates the domestic price increases which } \\
\text { leads to national trade deficit and deprives net } \\
\text { food sellers from receiving higher prices }\end{array}$ & Yang et al., 2017 \\
\hline $\begin{array}{l}\text { Inconsistence } \\
\text { of long-term } \\
\text { market prices } \\
\text { for agricultural } \\
\text { commodities } \\
\end{array}$ & $\begin{array}{l}\text { Volatile prices of agricultural commodities } \\
\text { impede agricultural business planning and cause } \\
\text { unwanted changes in international markets }\end{array}$ & $\begin{array}{l}\text { Josling et al., 2010; Tothova, } \\
\text { 2011; Roux, 2013, etc. }\end{array}$ \\
\hline $\begin{array}{l}\text { Existence } \\
\text { of agriculture in } \\
\text { disfavoured areas }\end{array}$ & $\begin{array}{l}\text { For social and environmental reasons, } \\
\text { agricultural activities are carried out in } \\
\text { unfavourable climatic, topographic, etc. areas }\end{array}$ & Zeeuw, 1997 \\
\hline
\end{tabular}


One of the main factors that determines the specificity of the international trade in agricultural products is the political strive to protect traditional economic and social values, i.e. politicians raise the aims to maintain traditional family farm systems (protect family farm revenues) that would face difficulties to survive in competitive international markets (Kay, 2009; Lenihan et al., 2009, etc.). What is more, the development of rural areas is treated as one of the top-priorities of the strategic development of a country or a region (Kay, 2009; Lenihan et al., 2009; Josling et al., 2010, etc.). For instance, the EU rural development policy, which is funded by the European Agricultural Fund for Rural Development (EAFRD), is worth $€ 100$ billion for the period 2014-2020 (the European Commission, 2016b). Such political attitudes leave the industrial sector in the role of "a stepdaughter" and sometimes are criticized for causing negative social and environmental consequences (Josling et al., 2010; Cai \& Song, 2016; Yang et al., 2017, etc.). Public attitudes are also often domestic-product favourable (Josling et al., 2010), and imported agricultural products are treated as a threat to domestic food and/or even consumer health security (Zeeuw, 1997; Wallinga, 2010).

Favourable political attitudes towards farm system protection and development of rural areas determine application of protectionist measures, such as introduction of high levies and tariffs to maintain internal prices above the level of the global prices, provision of subsidies, employment of deficiency payments and even bans on imports (Josling et al., 2010; Laborde \& Martin, 2012; Verter \& Bečvářová, 2014 and others). As it was earlier noted by Zeeuw (1997), in a large part of the EU countries, like Finland, Italy, Greece, Spain, Portugal, France, Germany, the UK and others, it is still believed that the trade in agricultural products could not survive without high protection. Nevertheless, previously mentioned protectionist measures distort the conditions of free market competition (i.e. ignore the rules of supply and demand) and lead to high consumer-paid prices and high governmental expenditure (on subsidization, direct payments, surplus removal, etc.). For this reason, the international trade in agricultural products may determine a balanced economic growth only in case trade restrictions and distortions are drastically reduced (McCally \& Nash, 2007; Verter, 2015, Verter \& Bečvářová,
2016). As it was stressed by Josling et al. (2010), by attempting to stabilise domestic prices and employing protectionist measures, governments exacerbate fluctuations of international markets. A number of authors (Josling et al., 2010; Grant, 2010; Franič \& Mikuš, 2013, etc.) provide the empirical findings that European Common Agricultural Policy (CAP) is wasteful as it causes overproduction and generates piles of product surplus which is either destroyed or dumped on developing countries. In this regard, the idea that the current European agricultural policy model is lacking of self-sufficiency and competitiveness (Franič \& Mikuš, 2013), and that the rules of free market supply-demand ratio would ensure higher efficiency of both the agricultural sector and the general economic development of the entire European region is proposed.

It is also the case that countries with high-cost agriculture try to keep their agricultural sectors closed rather than opened to international trade, which makes the trade in agricultural products close, imbalanced and diversified (an obvious corresponding relationship between trade potential and costs of agricultural products, i.e. the trend that high costs lead to inadequate trade, was identified by Wen et al. (2013), Cai and Song (2016) and others). Viju et al. (2017) emphasize the problem that the multilateral system of international trade thus far has not been able to open for the agricultural products that use biotechnology in their production. All of the above-mentioned arguments raise the doubts on whether economies are strongly promoted by the benefits of the international trade in agricultural products. What is more, Yang et al.'s (2017) empirical findings showed that incomplete price transmission mitigates the domestic price growth because domestic markets have to respond to high international prices. As a result, it cause an increase in the domestic trade deficit and deprives net food sellers from receiving high prices. The problem of inconsistent long-term market prices for agricultural commodities was also emphasized by Josling et al. (2010), Tothova (2011), Roux (2013), etc., and admitted by the European Commission itself (the European Commission, 2016a).

Another factor that determines the specificity of the international trade in agricultural products is existence of agriculture in disfavoured areas, i.e. the areas that are unfavourable for agricultural activities due to 
their adverse climate, land topography, poor fertility, etc. (Zeeuw, 1997). In this case, the principles of efficiency are violated for social and environmental reasons (e.g., support for small farms, preservation of some physical conditions, etc.).

The factors determining the specificity of the international trade in agricultural products raise many doubts on whether this type of international trade promotes national, regional (in particular, in the case of the EU) and global economic growth to such a large extent as it is considered. Of course, there is much empirical evidence to show that agricultural export, especially in developing countries, prompts foreign earnings and national income (Sanjuan-Lopez \& Dawson, 2010; Verter \& Bečvářová, 2014; Verter \& Bečvářová, 2016, etc.), brings the diversity of commodities (Verter \& Bečvářová, 2016), ensures a high level of commodity concentration (Karasova, 2016) and helps to maintain stable demand and supply (Erokhin et al., 2014). Nevertheless, it is also the case that agricultural sector does not necessarily serve as a leading sector for economic growth (Gollin, 2010), and agricultural policies may have contradictory effects on farm income and revenue risk. For instance, the results of Severini et al.'s (2017) research disclosed that on one hand, the European Common Agricultural Policy and protectionist measures reduce farmers' risk, which, in turn, allows them to involve in riskier activities, but on the other hand, it is less effective in terms of income stabilization as protectionist measures distort farmers' risk management behaviour. Furthermore, the support of agriculture-favourable policies sometimes requires keeping of national currency rates unchanged. For instance, the EU agricultural policy makers introduced dubbed green rates as specific exchange rates. However, in order to prevent arbitrage trade from undermining the resulting price differences between member countries, policymakers also had to introduce border taxes and subsidies for both intra- and extra-Community trade in agricultural products (called monetary compensatory amounts). The system soon became technically complex, with disastrous implications for economic efficiency" (Josling et al., 2010, p. 431).

Summarising, although the international trade in agricultural products is considered to promote national, regional and global economic growth by being one of the main sources of foreign earnings and national income as well as by ensuring the diversity of commodities for consumers and helping to maintain stable demand and supply, its impact on economically efficient growth is debatable as the international trade in agricultural products falls under the political strive to develop rural areas and maintain family farm systems which is implemented by employing numerous protectionist measures (import levies and tariffs, price protection, provision of subsidies, deficiency payments, bans on import, etc.). Supportive political attitudes along with employment of protectionist measures determine ignorance of the rules of supply and demand, distorted conditions of free market competition, closiness of the agricultural sector in comparison to other economic sectors, incomplete international agricultural price transmission, inconsistence of long-term market prices for agricultural commodities and existence of agriculture in disfavoured areas. What is more, as it was proved by some empirical studies, agricultural policies (in particular, the common EU agricultural policy) may have contradictory effects on farm income and revenue risk, and may require keeping of national currency rates unchanged, which, in turn, may have disastrous implications for economic efficiency. For the reasons explicated above, the authors of this article find it purposeful to research whether the international trade in agricultural products is a way to benefit from specialization and comparative advantage, i.e. whether it really promotes economic growth in EU 28. The methodology of the research is introduced in the further section of this article.

\section{Methodology for the Assessment of the Impact of the International Trade in Agricultural Products on the EU Economic Growth}

In scientific literature, classical assessment of the links between the phenomena under research is carried out by employing correlation analysis. In order to assess whether the EU international trade in agricultural products with different countries worldwide affects its economic growth, we employ the combination of Pearson correlation and multiple regression methods.

The point estimate of the population Pearson correlation coefficient (sample's 
Pearson correlation coefficient) is estimated by the formula (Janilionis, 2015):

$$
\hat{\rho}=\mathbf{r}=\frac{\overline{\mathbf{x y}}-\overline{\mathbf{x}} \cdot \overline{\mathbf{y}}}{\sqrt{\overline{\mathbf{x}^{2}}-(\overline{\mathbf{x}})^{2}} \sqrt{\mathbf{y}^{2}}-(\overline{\mathbf{y}})^{2}} .
$$

The multiple regression model refers to generalisation of a single variable linear regression model with more than one independent interval variable:

$$
Y=\hat{a}_{0}+\hat{a}_{1} x_{1}+\hat{a}_{2} x_{2}+\ldots+\hat{a}_{k} x_{k}+\hat{e} .
$$

Prognostication of the values of a dependent variable is one of regression purposes. Let us presume that the data comprises $n$ observations in a variable set: $\left(\mathrm{y}_{1}, \mathrm{x}_{11}, \mathrm{x}_{21}, \ldots\right.$ $\left.x_{k 1}\right),\left(y_{2}, x_{12}, x_{22}, \ldots x_{k 2}\right), \ldots,\left(y_{n}, x_{1 n}, x_{2 n}, \ldots x_{k n}\right)$. The aim is to find the values $a_{0}, a_{1}, a_{2}, \ldots, a_{k}$ for parameters $\hat{a}_{0}, \hat{a}_{1}, \hat{a}_{2}, \ldots, \hat{a}_{k}$ so that the function's $\hat{y}(\vec{x})=\hat{y}\left(x_{1}, x_{2}, \ldots, x_{k}\right)=a_{0}+a_{1} x_{1}+a_{2} x_{2}+\ldots+a_{k} x_{k}$ estimates at the points $\left(\mathrm{x}_{1 \mathrm{i}}, \mathrm{x}_{2 \mathrm{i}}, \ldots \mathrm{x}_{\mathrm{ki}}\right)$ would as little as possible vary from $y_{i}, i=1,2, \ldots, n$. The above-mentioned values are selected by applying the least squares method, i.e. they are selected so that residual errors $\hat{e}_{i}=y_{i}-\hat{y}\left(\vec{x}_{i}\right)=y_{i}-\left(a_{0}+a_{1} x_{1 i}+a_{2} x_{2 i}+\ldots+a_{k} x_{k i}\right)$, would show the lowest square sum SSE $=\sum^{n} \hat{\mathrm{e}}_{\mathrm{i}}^{2}$. This way, function $\hat{y}(\vec{x})$, called a regression function, is developed. Prognosticated value $Y$ is obtained by filling function $\hat{y}(\vec{x})$ with values $\mathrm{x}_{1}, \mathrm{x}_{2}, \ldots, \mathrm{x}_{\mathrm{k}}$, which fall into the data coverage area, i.e. $x_{i} \in\left(\min x_{i j}, \max _{i} x_{i j}\right)$.

For implementation of the research purpose, time period 2000-2016 and 12y (Gross domestic product, unemployment, self-employed, employment in agriculture, goods and services expense, compensation of employees, subsidies and other transfers, labour force, tax revenue, inflation, foreign direct investment, total governmental final consumption expenditure) values describing economic growth were selected (see Tab. 2).

\section{Tab. 2: Description of dependent variables (Part 1)}

\begin{tabular}{c|l|l|l} 
No. & \multicolumn{1}{|c|}{ Dependent variable (y) } & \multicolumn{1}{c}{ Description and data source } \\
\hline 1. & $\begin{array}{l}\text { Gross domestic product at } \\
\text { market prices, million euro }\end{array}$ & $\begin{array}{l}\text { GDP (gross domestic product) is an indicator for a nation's } \\
\text { economic situation. It reflects the total value of all goods and } \\
\text { services produced less the value of goods and services used for } \\
\text { intermediate consumption in their production (Source: Eurostat). }\end{array}$ \\
\hline 2. & $\begin{array}{l}\text { Unemployment, thousands } \\
\text { persons }\end{array}$ & $\begin{array}{l}\text { Unemployed persons are all persons 15 to 74 years of age (16 to } \\
74 \text { years) who were not employed during the reference week, had } \\
\text { actively sought work during the past four weeks and were ready to } \\
\text { begin working immediately or within two weeks (Source: Eurostat). }\end{array}$ \\
\hline 3. & $\begin{array}{l}\text { Self-employed, total (\% of } \\
\text { total employment) }\end{array}$ & $\begin{array}{l}\text { Self-employed workers are those workers who, working on their } \\
\text { own account or with one or a few partners or in cooperative, hold } \\
\text { the type of jobs defined as a ,self-employment jobs." i.e. jobs where } \\
\text { the remuneration is directly dependent upon the profits derived } \\
\text { from the goods and services produced. Self-employed workers } \\
\text { include four sub-categories of employers, own-account workers, } \\
\text { members of producers cooperatives, and contributing family } \\
\text { workers (Source: World Bank). }\end{array}$ \\
\hline 4. & $\begin{array}{l}\text { Employment in agriculture } \\
\text { (\% of total employment) }\end{array}$ & $\begin{array}{l}\text { Employment is defined as persons of working age who were } \\
\text { engaged in any activity to produce goods or provide services for } \\
\text { pay or profit, whether at work during the reference period or not } \\
\text { at work due to temporary absence from a job, or to working-time } \\
\text { arrangement (Source: World Bank). }\end{array}$ \\
\hline 5. & $\begin{array}{l}\text { Goods and services } \\
\text { expense (\% of expense) }\end{array}$ & $\begin{array}{l}\text { Goods and services include all government payments in exchange } \\
\text { for goods and services used for the production of market and } \\
\text { nonmarket goods and services. Own-account capital formation is } \\
\text { excluded (Source: World Bank). }\end{array}$ \\
\hline
\end{tabular}




\section{Tab. 2: Description of dependent variables (Part 2)}

\begin{tabular}{|c|c|c|}
\hline No. & Dependent variable (y) & Description and data source \\
\hline 6. & $\begin{array}{l}\text { Compensation of } \\
\text { employees ( } \% \text { of expense) }\end{array}$ & $\begin{array}{l}\text { Compensation of employees consists of all payments in cash, as } \\
\text { well as in kind (such as food and housing), to employees in return } \\
\text { for services rendered, and government contributions to social } \\
\text { insurance schemes such as social security and pensions that } \\
\text { provide benefits to employees (Source: World Bank). }\end{array}$ \\
\hline 7. & $\begin{array}{l}\text { Subsidies and other } \\
\text { transfers (\% of expense) }\end{array}$ & $\begin{array}{l}\text { Subsidies, grants, and other social benefits include all unrequited, } \\
\text { non-repayable transfers on current account to private and } \\
\text { public enterprises; grants to foreign governments, international } \\
\text { organizations, and other government units; and social security, } \\
\text { social assistance benefits, and employer social benefits in cash and } \\
\text { in kind (Source: World Bank). }\end{array}$ \\
\hline 8. & Labour force & $\begin{array}{l}\text { Labour force comprises people ages } 15 \text { and older who supply labour } \\
\text { for the production of goods and services during a specified period. } \\
\text { It includes people who are currently employed and people who are } \\
\text { unemployed but seeking work as well as first-time job-seekers. } \\
\text { Labour force size tends to vary during the year as seasonal workers } \\
\text { enter and leave (Source: World Bank). }\end{array}$ \\
\hline 9. & Tax revenue (\% of GDP) & $\begin{array}{l}\text { Tax revenue refers to compulsory transfers to the central } \\
\text { government for public purposes. Certain compulsory transfers } \\
\text { such as fines, penalties, and most social security contributions are } \\
\text { excluded. Refunds and corrections of erroneously collected tax } \\
\text { revenue are treated as negative revenue (Source: World Bank). }\end{array}$ \\
\hline 10. & $\begin{array}{l}\text { Inflation, consumer prices } \\
\text { (annual \%) }\end{array}$ & $\begin{array}{l}\text { Inflation as measured by the consumer price index reflects the } \\
\text { annual percentage change in the cost to the average consumer } \\
\text { of acquiring a basket of goods and services that may be fixed or } \\
\text { changed at specified intervals, such as yearly. The Laspeyres } \\
\text { formula is generally used (Source: World Bank). }\end{array}$ \\
\hline 11. & $\begin{array}{l}\text { Foreign direct investment, } \\
\text { net inflows (BoP, current } \\
\text { US\$) }\end{array}$ & $\begin{array}{l}\text { Foreign direct investment refers to direct investment equity flows in } \\
\text { the reporting economy. It is the sum of equity capital, reinvestment } \\
\text { of earnings, and other capital. Direct investment is a category } \\
\text { of cross-border investment associated with a resident in one } \\
\text { economy having control or a significant degree of influence on the } \\
\text { management of an enterprise that is resident in another economy } \\
\text { (Source: World Bank). }\end{array}$ \\
\hline 12. & $\begin{array}{l}\text { Total governmental final } \\
\text { consumption expenditure } \\
\text { (annual \% growth) }\end{array}$ & $\begin{array}{l}\text { Annual percentage growth of the total governmental final } \\
\text { consumption expenditure based on constant local currency. } \\
\text { Aggregates are based on constant } 2010 \text { U.S. dollars. Total } \\
\text { governmental final consumption expenditure (total governmental } \\
\text { consumption) includes all current governmental expenditure for } \\
\text { purchases of goods and services (including compensation of } \\
\text { employees). It also includes expenditure on national defence and } \\
\text { security, but excludes governmental military expenditure that is part } \\
\text { of government capital formation (Source: World Bank). }\end{array}$ \\
\hline
\end{tabular}


For $x$ cases under consideration, the following expressions are attributed: $x 1-E U 28$ total import of agricultural products; $x 2$ - EU28 total export of agricultural products; x3 - EU28 (Section I: Live animals; animal products) export and x4 EU28 section I import; x5 - EU28 (Section II: vegetable products) export and x6 - EU28 section II import; x7 - EU28 (Section III: Animal or vegetable fats and oils and their cleavage products' prepared edible fats; animal and vegetable waxes) export and EU28 x8 section III import; x9 - EU28 (IV: prepared foodstuffs; beverages, spirits and vinegar; tobacco and manufactured tobacco substitutes) export and x10 - EU28 section IV import.

Complex multi-regression calculations were performed by employing modern computer software: specialised packages for statistical data analysis (SPSS) and Ms Excel's specialized sub-system Data Analysis (Regression module).

\section{The Results of the Empirical Research on the Impact of the International Trade in Agricultural Products on the EU Economic Growth}

The calculations of Pearson correlation between the import of agricultural products from all over the world to the EU and 12 indicators describing the growth of the EU economy disclosed statistically significant relationship only between EU28 import and export of agricultural products and the following variables (see Tab. 3).

\section{Tab. 3: Correlation matrix}

\begin{tabular}{l|l|c|c|c|c|c} 
& & Y1 & Y3 & Y4 & Y7 & Y8 \\
\hline EU 28 Total & Pearson Correlation & 0.958 & -0.907 & -0.917 & 0.774 & 0.947 \\
Export & Sig. (2-tailed) & 0.000 & 0.000 & 0.000 & 0.000 & 0.000 \\
\hline EU 28 Total & Pearson Correlation & 0.970 & -0.927 & -0.936 & 0.746 & 0.961 \\
Import & Sig. (2-tailed) & 0.000 & 0.000 & 0.000 & 0.000 & 0.000 \\
\hline
\end{tabular}

$\mathrm{y} 1-$ GDP in market prices $\left(r_{\text {1import }}=0.970\right.$ $\left.(p=0.000) ; r_{1 \text { export }}=0.958(p=0.000)\right)$;

y3 - the number of the self-employed (percentage of the number of the employed); $\left(r_{3 i m p o r t}=-0.927(p=0.000) ; r_{3 \text { export }}=-0.907\right.$ $(p=0.000))$;

y4 - employment in the agricultural sector (percentage of the total employment); $\left(r_{\text {4import }}=-0.936(p=0.000) ; r_{\text {4export }}=-0.917\right.$ $(p=0.000))$

y7 - subsidies and other transfers (percentage of expenditure); $\left(r_{7 \text { import }}=0.746\right.$ $\left.(p=0.000) ; r_{\text {7export }}=0.774(p=0.000)\right)$;

y8 - labour force rate; $\left(r_{\text {8import }}=0.961\right.$ $\left.(p=0.000) ; r_{\text {8export }}=0.947(p=0.000)\right)$;

Further in the article, the results of multiple regression have been presented only for the variables with value $|r|$ equal or higher than 0.6 (see Tab. 4).

The empirical research has revealed very interesting results:

1. International trade (both export and import) in agricultural products mainly affects, the EU economy but only insignificant part, through the following indicators: GDP, selfemployment, employment in the agricultural sector, subsidies and other transfers, labour force rate.

2. The impact of sections I and III export and import coincided for 4 (GDP, selfemployment, subsidies and other transfers, and labour force rate) out of 6 statistically significant indicators, which proposes that in further studies import and export of agricultural products can be researched as a single expression, i.e. international trade in agricultural products.

3. Over the period 2000-2016, the volumes of section I (live animals and animal products) of the international trade in agricultural products had the most significant impact on GDP, self-employment, subsidies and other transfers, and labour force rate.

4. Calculations for section IV (prepared foodstuffs; beverages spirits and vinegar; tobacco and manufactured tobacco 
Tab. 4: The results of multiple regression (Part 1)

\begin{tabular}{|c|c|c|}
\hline $\mathbf{Y}$ & Multiple regression equation & Result \\
\hline GDP & $\begin{array}{l}\text { GDP }\left(\mathrm{y}_{1}\right)=2.046 \mathrm{E}-0.4^{*} \mathrm{I} \text { section } \\
\text { I import+3.537E-0.4* section III import } \\
\text { GDP }\left(\mathrm{y}_{1}{ }^{-}\right)=2.636 \mathrm{E}-0.4^{*} \text { section I export- } \\
0.001^{*} \text { section III export } \\
\text { Interpretation: } \\
\text { When section I import grow by } 1 \text {, GDP } \\
\text { increases by } 2.046 \mathrm{E}-0.4 \text { Eur in case other } \\
\text { conditions remain unchanged. } \\
\text { When section III import increases by } \\
1, \text { GDP increases by } 3.537 \mathrm{E}-04 \text { Eur in } \\
\text { case other conditions remain unchanged. } \\
\text { Corresponding interpretation can be } \\
\text { provided concerning export's impact on } \\
\text { GDP. } \\
\text { Standardized beta coefficients show that } \\
\text { GDP is most significantly affected by } \\
\text { section I import (1.515) and export (1.961), } \\
\text { while least significantly - by section III } \\
\text { import (-0.526) and export (-0.975). }\end{array}$ & $\begin{array}{l}\text { An increase in the volumes } \\
\text { of the international trade in } \\
\text { section I (live animal and animal } \\
\text { products) and III (animal or } \\
\text { vegetable fats and oils and their } \\
\text { cleavage products; prepared } \\
\text { edible fats; animal or vegetable } \\
\text { waxes) products has a positive } \\
\text { impact on GDP, and vice versa. } \\
\text { The impact of the international } \\
\text { trade in section I products is } \\
\text { most significant. }\end{array}$ \\
\hline $\begin{array}{l}\text { Self-employed, total } \\
\text { (\% from employed) }\end{array}$ & $\begin{array}{l}\text { Self-employed }\left(\mathrm{y}_{2}\right)=4.319 \mathrm{E}-10^{*} \text { section } \\
\text { I import-1.280-E9* section III import } \\
\text { Self-employed }\left(\mathrm{y}_{2-2}\right)=5.875 \mathrm{E}-10^{*} \text { section } \\
\text { I export-2.458E-09*section III export } \\
\text { Interpretation: } \\
\text { When section I import increased by } 1 \text {, the } \\
\text { number of self-employed grows by } 4.319 \mathrm{E}- \\
10 \text { percent in case other conditions remain } \\
\text { unchanged. } \\
\text { When section III import decreases by } 1 \text {, the } \\
\text { number of self-employed drops by } 1.280- \\
\text { E9 percent in case other conditions remain } \\
\text { unchanged. Corresponding interpretation } \\
\text { can be provided concerning export's impact } \\
\text { on self-employment. } \\
\text { Standardized beta coefficients show that } \\
\text { self-employment is most significantly } \\
\text { affected by section I import (2.352) and } \\
\text { export (3.204), while least significantly - } \\
\text { by section III import (-1.401) and export } \\
(-2.255), \text { but the impact of section I and } \\
\text { section III export on self-employment is } \\
\text { more significant than that of import. }\end{array}$ & $\begin{array}{l}\text { An increase in the volumes } \\
\text { of the international trade in } \\
\text { section I (live animal and animal } \\
\text { products) and III (animal or } \\
\text { vegetable fats and oils and their } \\
\text { cleavage products; prepared } \\
\text { edible fats; animal or vegetable } \\
\text { waxes) products has a positive } \\
\text { impact on the number of self- } \\
\text { employed, and vice versa. } \\
\text { The impact of the international } \\
\text { trade in section I products is } \\
\text { most significant. }\end{array}$ \\
\hline
\end{tabular}


Employment in the agricultural sector (percentage of total employment)

Subsidies and other transfers
Employment in the agricultural sector $\left(\mathrm{y}_{4}\right)$ $=9.385+1.066 \mathrm{E}-10 *$ section I import1.073E-10*section III import-8.685E11*section IV import.

Employment in the agricultural sector $\left(\mathrm{y}_{4-4}\right)$ $=2.672 \mathrm{E}-10^{*}$ section I export-1.259E09*section III export.

Interpretation:

When section I import grows by 1 , the number of employed in the agricultural sector increases by $1.066 \mathrm{E}-10$ percent in case other conditions remain unchanged. When section III import decreases by 1 , the number of employed in the agricultural sector decrease by $1.073 \mathrm{E}-10$ percent in case other conditions remain unchanged. When section IV import decreases by 1 , the number of employed in the agricultural sector decreases by $8.685 \mathrm{E}-11$ percent in case other conditions remain unchanged.

Corresponding interpretation can be provided concerning export's impact on employment in the agricultural sector, apart from section IV.

Standardized beta coefficients show that employment in the agricultural sector is most significantly affected by section IV import (-2.912) and section I export (4.271), while least significantly - by section III import $(-0.655)$ and section III export (-3.378).

Subsidies and other transfers $\left(\mathrm{y}_{7}\right)$ $=-2.799 \mathrm{E}-0.9-1.406-\mathrm{E}^{*}$ section III import+1.083E-09+2.015-E*section I import

Subsidies and other transfers $\left(\mathrm{y}_{7-7}\right)=$ $-1.437 \mathrm{E}-0.9^{*}$ section I export-5.480E09*section III export

Interpretation:

When section III import drops by 1 , subsidies and other transfers reduce by 1.406-E percent in case other conditions remain unchanged.

When section I import rise by 1 , subsidies and other transfers increase by $2.015-\mathrm{E}$ percent in case other conditions remain unchanged. Corresponding interpretation can be provided concerning export's impact on subsidies and other transfers.

Standardized Beta coefficients show that subsidies and other transfers are most significantly affected by section I import (2.01) and export (2.685), while least significantly - by section III import (-1.4) and export (-1.718).
An increase in the volumes of the import of section I (live animal and animal products), III (animal or vegetable fats and oils and their cleavage products; prepared edible fats; animal or vegetable waxes) and IV (prepared foodstuffs; beverages spirits and vinegar; tobacco and manufactured tobacco substitutes) products has a positive impact on employment in the agricultural sector, and vice versa. In case of export, only sections I and III were found to affect employment in the agricultural sector.

The impact of section IV import and section I export is most significant.
An increase in the volumes of the international trade in section I (live animal and animal products) and III (animal or vegetable fats and oils and their cleavage products; prepared edible fats; animal or vegetable waxes) products has a positive impact on subsidies and other transfers, and vice versa. The impact of the international trade in section I products is most significant. 


\section{Tab. 4: The results of multiple regression (Part 3)}

\begin{tabular}{|c|c|c|}
\hline $\begin{array}{l}\text { Labour force rate, } \\
\text { people }\end{array}$ & $\begin{array}{l}\text { Labour force rate }\left(\mathrm{y}_{8}\right)=0.005^{*} \text { section } \\
\text { I import- } 0.013^{*} \text { section III import } \\
\text { Labour force rate }\left(\mathrm{y}_{8-8}\right)=-0.007^{*} \text { section } \\
\text { I export- } 0.027^{*} \text { section III export } \\
\text { Interpretation: } \\
\text { When section I import rises by } 1 \text {, labour } \\
\text { force rate increases by } 0.005 \text { people in } \\
\text { case other conditions remain unchanged. } \\
\text { When section III import drops by } 1 \text {, labour } \\
\text { force rate decreases by } 0.013 \text { people in } \\
\text { case other conditions remain unchanged. } \\
\text { Corresponding interpretation can be } \\
\text { provided concerning export's impact on } \\
\text { labour force rate. } \\
\text { Standardized beta coefficients show that } \\
\text { labour force rate is most significantly } \\
\text { affected by section I import (2.017) and } \\
\text { export, }(2.704) \text {, while least significantly - } \\
\text { by section III import (-1.408) and export } \\
(-1.738) \text {. }\end{array}$ & $\begin{array}{l}\text { An increase in the volumes } \\
\text { of the international trade in } \\
\text { section I (live animal and animal } \\
\text { products) and III (animal or } \\
\text { vegetable fats and oils and their } \\
\text { cleavage products; prepared } \\
\text { edible fats; animal or vegetable } \\
\text { waxes) products has a positive } \\
\text { impact on labour force rate, and } \\
\text { vice versa. } \\
\text { The impact of the international } \\
\text { trade in section I products is } \\
\text { most significant. }\end{array}$ \\
\hline
\end{tabular}

substitutes) indicated that import had the most significant impact on employment in the agricultural sector (2.912), although beta coefficient for section I export was higher (4.271). The same tendency was captured for total governmental final consumption expenditure: section IV import beta coefficient amounted to -11.750 , while section I export beta coefficient was equal to $(-4,304)$.

Summarising, the following conclusions can be developed:

The growth in the volumes of the international trade in agricultural products determines the growth in GDP, but only insignificant part. The research has revealed the strength of the impact of the international trade in agricultural products on economic growth described by GDP (y1). The results show that the relationship between the international trade in agricultural products and GDP $\left(r_{\text {1import }}=0.970 ; r_{1 \text { export }}=0.958\right)$ is very strong. Over the last few decades, scientific studies have confirmed the significance of the impact of international trade on national economic growth and have highlighted the transmission of this impact to other countries. The theories of international trade also stress that the impact of separate countries and regions on economic growth manifests at both national and regional levels. Hence, the findings of this research confirm the economic benefits of the international trade in agricultural products (in particular, section I and III products).

The growth in the number of the selfemployed (y3) reduces the volumes of the international trade in agricultural products, even though insignificantly $\left(r_{\text {3import }}=-0.927\right.$; $r_{\text {3export }}=-0.907$ ). Such result can be explained by considering the fact that since 2015, the number of the self-employed has been rapidly growing. Although the relationship between the above-mentioned variables is negative, the positive tendency is that promotion of selfemployment has become more intensive since the post-crisis period.

Other reasons, related to subsidy programs, which resulted in updating technologies and innovations, introduced into agriculture, resulted a decrease in the demand for human capital, including self-employment. In addition, prices for agricultural products have been steadily rising (in the context of EU change in price indices).

The growth in subsidies and other transfers $\left(y_{7}\right)$ determines the growth in the volumes of the international trade in agricultural products $\left(r_{7 \mathrm{import}}=0.746\right.$; 
$\left.r_{7 \text { export }}=0.774\right)$. With reference to the forecasts of the European Commission (2017), the future growth of the EU economy should be rapid. The economists emphasize the improvement of the labour market indicators and high values of economic confidence indicators. What is more, the global economic activity and international trade are growing faster than it was expected. Germany and France, the largest countries of the Eurozone, are also prognosticated to show the trends of further economic development. In 2017, the extremely intensive economic growth was recorded in Poland. The UK is predicted to have much slower economic growth in comparison to the EU member states due to the effects of Brexit. In addition, subsidies of exported products in during 2002-2013, made a positive impact on increased export volumes.

The growth in the volumes of the international trade in agricultural products $\left(x_{8}\right)$ determines the growth in labour force rate $\left(r_{8 i m p o r t}=0.961 ; r_{\text {8export }}=0.947\right)$. Although labour markets are reviving, some EU member states are still facing social difficulties. Since the middle of 2013 , the situation in the labour market has been improving; the gaps in the unemployment rate recorded in different EU member states are shrinking, which can be considered a positive tendency. Nevertheless, some EU member states, in particular those with the most serious consequences of the financial and debt crisis, are still suffering extremely high unemployment rates, low wages and social difficulties.

The reduction of the volumes of the international trade in agricultural products determines the growth in employment in the agricultural sector $\left(r_{\text {4import }}=-0.936(p=0.000)\right.$; $\left.r_{\text {4export }}=-0.917(p=0.000)\right)$. This tendency can be explained by considering the fact that the growing unemployment rate, decreasing wages, rising household debt repayment costs and unfavourable future expectations, all caused by the global economic crisis, have inevitably led to the decline in domestic and foreign markets, which, in turn, has negatively affected the volumes of the international trade in all kinds of products and services, including agricultural products. After the economic crisis of 2007-2008, the number of people working in the agricultural sector has been steadily increasing, which has been determined by favourable agricultural lending policies, guarantees for farmers, a relatively rational agriculture taxation system, constantly supported income of agricultural workers and properly implemented structural polices. On the other hand, the justification could be related to the case of self-employment.

\section{Conclusions}

The comprehensive analysis of the scientific literature has disclosed that supportive political attitudes towards the agricultural sector along with employment of protectionist measures determine ignorance of the rules of supply and demand, distortion of the conditions of free market competition, closiness of the agricultural sector in comparison to other economic sectors, incomplete international agricultural price transmission, inconsistence of long-term market prices for agricultural commodities and existence of agriculture in disfavoured areas.

The empirical research has revealed a very strong linear relationship between the international trade in agricultural products and GDP, however only insignificant part; over the last few decades, the significance of this relationship has been increasingly emphasized in the context of international trade as the impact of international trade on national and regional economic growth and transmission of this impact to other countries and regions is incontestable. The theories of international trade also stress that the impact of separate countries and regions on economic growth manifests at both national and regional levels. Hence, the findings of this research confirm the economic benefits of the international trade in agricultural products (in particular, section I and III products).

It has been found that the international trade in agricultural products significantly affects labour market (insignificantly), which is one of the main areas reflecting the state of national or regional economics. When the volumes of the international trade in agricultural products are increasing/decreasing, labour force rate, the number of self-employed and the number of employed in the agricultural sector are also increasing/decreasing. Hence, the volumes of the international trade affect the EU employment rate. The correlation analysis has revealed that the growth in the number of the self-employed determines the reduction in the volumes of international trade in agricultural products. Such result can be explained by considering the fact that since 2015 , the number 
of the self-employed has been rapidly growing. Although the relationship between the abovementioned variables is negative, the positive tendency is that promotion of self-employment has become more intensive since the post-crisis period. By economic industries, in 2015 , like at the beginning of 2016, the largest number of the self-employed worked in the agricultural sector (nearly 15 percent of the total number of self-employed). This statistic indicates that self-employment in the agricultural sector is becoming increasingly important for the development of the EU international trade and economics. Since 2015, the number of the self-employed, which had been constantly decreasing, has started to be promoted by employing various EU programs (2014-2020 EU structural fund investment action programs for employment) that are expected to produce effective results in the target area. The results of the multiple regression analysis have disclosed that only the international trade in section I and III products significantly contributes to promotion of self-employment.

The estimations have disclosed that while analysing the impact of the international trade in agricultural products on economic growth, there is no necessity to research export and import volumes in separate as agricultural export and import show nearly the same (only with insignificant value differences) determinants of economic growth promotion.

It has been found that over the period 20002016, the international trade in agricultural products mainly comprises the trade in live animals and animal products as well as animal or vegetable fats and oils and their cleavage products; prepared edible fats; animal or vegetable waxes. The above-mentioned product sections had the most significant impact on the indicators of the EU economic growth: GDP at market prices, self-employment, employment in agriculture, labour force rate, subsidies and other transfers.

Limitations of the research: due to statistical data availability the analysis was conducted for the year of 2000-2016. In addition, due to the time gap, it was not possible to add more indicators reflecting economic growth.

Future research possibilities: to identify which EU country or group of countries of the international trade in agricultural products has the greatest impact on EU economic growth and, as a result, to present the best practices based on the experience of these countries and the policy for promoting international trade in agricultural products.

Mathematical calculations have shown that international trade in agricultural products is important for improving the labor market indicators, as a result, it is proposed that EU policy makers continue to focus on forms of subsidies and incentives for entrepreneurship of self-employment and employment in the agricultural sector. In addition, it is recommended to facilitate the transition of selfemployed people to the creation of their own business and and their ability to hire people.

\section{References}

Adhikary, B. K. (2010). FDI, Trade Openness, Capital Formation, and Economic Growth in Bangladesh: a Linkage Analysis. International Journal of Business and Management, 6(1), 16-28. https://dx.doi.org/10.5539/ijbm.v6n1p16.

Busse, M., \& Koniger, J. (2012). Trade and economic growth: a re-examination of the empirical evidence. Retrieved from https://www. ifw-kiel.de/konfer/staff-seminar/paper/2012/ Koeniger.pdf.

Cai, H., \& Song, Y. (2016). The state's position in international agricultural commodity trade: a complex network. China Agricultural Economic Review, 8(3), 430-442. https://dx.doi. org/10.1108/CAER-02-2016-0032.

Erokhin, V., Ivolga, A., \& Heijman, W. (2014). Trade liberalization and state support of agriculture: effects for developing countries. Agricultural Economics - Czech, 60(11), 354-366. https://doi.org/10.17221/137/2013AGRICECON.

Fetahi-Vehapi, M., Sadiku, L., \& Petkovski, M. (2015). Empirical Analysis of the Effects of Trade Openness on Economic Growth: An Evidence for South East European Countries. Procedia Economics and Finance, 19, 17-26. https://doi.org/10.1016/S2212-5671(15)00004-0.

Food and Agriculture Organization of the United Nations. (2009). Global agriculture towards 2050. Rome: High Level Expert Forum, Agricultural Development Economics Division. Retrieved May 25, 2018, from http://www.fao. org/fileadmin/templates/wsfs/docs/Issues_ papers/HLEF2050_Global_Agriculture.pdf.

Franič, R., \& Mikuš, O. (2013). Transformations in Croatian Agriculture and Agricultural Policy: Challenges and Opportunities within the European Context. 
In D. Ortiz-Miranda, A. Moragues-Faus, \& E. Arnalte-Alegre (Eds.), Agriculture in Mediterranean Europe: Between Old and New Paradigms (Research in Rural Sociology and Development, Volume 19) (pp. 233-261). Emerald Group Publishing Limited.

Gollin, D. (2010). Agricultural productivity and economic growth. Handbook of Agricultural Economics, 4, 3825-3866. https://dx.doi. org/10.1016/S1574-0072(09)04073-0.

Grant, W. (2010). Policy instruments in the common agricultural policy. West European Politics, 33(1), 22-38. https://dx.doi. org/10.1080/01402380903354049.

Henneberry, D. M., \& Curry, K. (2010). Agricultural import demand in large markets: an aggregate analysis with high and low growth subgroups. Journal of Food Products Marketing, 2(3), 67-87.

Hidayatie, E. P. (2014). Agricultural trade, economic growth and free trade agreements: studies of the Indonesian case. Retrieved April 18, 2018, from http://vuir.vu.edu.au/29991/1/ Estty\%20Purwadiani\%20Hidayatie.pdf.

Josling, T., Anderson, K., Schmitz, A., \& Tangermann, S. (2010). Understanding international trade in agricultural products: one hundred years of contributions by agricultural economists. Retrieved April 15, 2018, from https://fsi.stanford.edu/sites/default/files/ Understanding_International_Trade.pdf.

Kay, C. (2009). Development strategies and rural development: exploring synergies, eradicating poverty. The Journal of Peasant Studies, 36(1), 103-137. https://dx.doi. org/10.1080/03066150902820339.

Karasova, N. (2016). Comparative advantages in international trade of Ukrainian agriculture. Management Theory and Studies for Rural Business and Infrastructure Development, 38(2), 230-239. https://dx.doi. org $/ 10.15544 / \mathrm{mts}$.

Ključnikov, A., \& Popesko, B. (2017). Export and its Financing in The SME Segment. Case Study From Slovakia. Journal of Competitiveness, 9(1), 20-35. https://dx.doi. org/10.7441/joc.2017.01.02.

Laborde, D., \& Martin, W. (2012). Agricultural trade: what matters in the Doha round? Annual Review of Resource Economics, 4, 265-283.

Lenihan, M. H., Brasier, K. J., \& Stedman, R. C. (2009). Chapter 5 Perceptions of agriculture's multifunctional role among rural Pennsylvanians In Kjell Andersson, Minna
Lehtola, Erland Eklund, \& Pekka Salmi (Eds.), Beyond the Rural-Urban Divide: CrossContinental Perspectives on the Differentiated Countryside and its Regulation (Research in Rural Sociology and Development, Volume 14) (pp. 127-149). Emerald Group Publishing Limited.

Markovič, I., \& Markovič, M. (2014). Agricultural protectionism of the European Union in the conditions of international trade liberalization. Retrieved April 12, 2018, from http://ageconsearch.umn.edu/ bitstream/175292/2/11\%20EP\%202\%20201411.pdf.

McCally, A. F., \& Nash, J. (2007). Reforming agricultural trade for developing countries: volume one key issues for a pro-development outcome of the Doha Round. Washington D.C.: World Bank.

Roux, N. (2013). Volatility in global agricultural commodity markets and changes in consumer food prices in France. Retrieved April 10, 2018, from https://www.economie. gouv.fr/files/files/directions_services/dgccrf/ documentation/dgccrf_eco/english/dgccrf_ eco12_volatility_global_agricultural_markets. pdf.

Sanjuan-Lopez, A. I., \& Dawson, P. J. (2010). Agricultural exports and economic growth in developing countries: a panel cointegration approach. Journal of Agricultural Economics, 61(3), 565-583. https://dx.doi. org/10.1111/j.1477-9552.2010.00257.x.

Severini, S., Tantari, A., \& Di Tommaso, G. (2017). Effect of agricultural policy on income and revenue risks in Italian farms: implications for the use of risk management policies. Agricultural Finance Review, 77(2), 295-311. https://doi.org/10.1108/AFR-07-2016-0067.

Simionescu, M., Lazányi, K., Sopková, G., Dobeš, K., \& Balcerzak, A. P. (2017). Determinants of Economic Growth in V4 Countries and Romania. Journal of Competitiveness, 9(1), 103-116. https://dx.doi. org/10.7441/joc.2017.01.07.

Shah, S. W. A., Abrar ul haq, M., \& Farooq, R. M. A. (2015). Agricultural export and economic growth: a case study of Pakistan [MPRA Paper No. 67249]. Munich Personal RePEc Archive. Retrieved April 30, 2018, from https://mpra.ub.uni-muenchen.de/67249/1/ MPRA_paper_67249.pdf.

Sun, P., \& Heshmati, A. (2010). International trade and its effects on economic growth in 
China [IZA Discussion Paper No. 5151]. Bonn: Institute for the Study of Labor. Retrieved April 30, 2018, from http://ftp.iza.org/dp5151.pdf.

The European Commission. (2016a). Agricultural markets and international trade. Retrieved April 20, 2018, from https://ec.europa. eu/jrc/en/research-topic/agricultural-marketsand-international-trade.

The European Commission. (2016b). Rural development 2014-2020. Retrieved May 10, 2018, from https://ec.europa.eu/agriculture/ rural-development-2014-2020_en.

Tothova, M. (2011). Main Challenges of Price Volatility in Agricultural Commodity Markets. In I. Piot-Lepetit, \& R. M'Barek (Eds.), Methods to Analyse Agricultural Commodity Price Volatility (pp. 13-29). New York: Springer. https://dx.doi.org/10.1007/978-1-4419-7634-5 2.

Verter, N. (2015). The application of international trade theories to agriculture. Mediterranean Journal of Social Sciences, 6(6), 209-219. https://doi.org/10.5901/mjss.2015. v6n6s4p209.

Verter, N., \& Bečvářová, V. (2014). Analysis of some drivers of cocoa export in Nigeria in the era of trade liberalization. Agris On-Line Papers in Economics and Informatics, 6(4), 208-218.

Verter, N., \& Bečvářová, V. (2016). The impact of agricultural exports on economic growth in Nigeria. Acta Universitatis Agriculturae et Silviculturae Mendelianae Brunensis, 64(2), 691-700. https://dx.doi.org/10.11118/ actaun201664020691.

Viju, C., Smyth, S. J., \& Kerr, W. A. (2017). Agricultural Biotechnology and Food Security: Can CETA, TPP, and TTIP Become Venues to Facilitate Trade in GM Products? In A. Schmitz, P. Lynn Kennedy, \& T. G. Schmitz (Eds.), World Agricultural Resources and Food Security (Frontiers of Economics and Globalization, Volume 17) (pp. 191-206). Emerald Publishing Limited.

Vojtovič, S. (2016). The Impact of the Structural Funds on Competitiveness of Small and Medium-Sized Enterprises. Journal of Competitiveness, 8(4), 30-45. https://dx.doi. org/10.7441/joc.2016.04.02.

Wallinga, D. (2010). Agricultural policy and childhood obesity: a food systems and public health commentary. Health Affairs, 29(3), 405-410. https://dx.doi.org/10.1377/ hlthaff.2010.0102.
Wang, X., Chen, H., \& Li, S. (2017). Effect of export promotion programs on export performance: evidence from manufacturing SME's. Journal of Business Economics and Management, 18(1), 131-145. https://dx.doi. org/10.3846/16111699.2016.1278031.

Wen, S., Zheng, J., \& Liu, X. (2013). An analysis on China's agricultural bilateral trade costs? 1995-2007. China Agricultural Economic Review, 5(3), 360-372. https://doi.org/10.1108/ CAER-10-2011-0134.

Yang, F., Urban, K., Brockmeier, M., Bekkers, E., \& Francois, J. (2017). Impact of increasing agricultural domestic support on China's food prices considering incomplete international agricultural price transmission. China Agricultural Economic Review, 9(4), 535-557. https://doi.org/10.1108/CAER-01-2016-0001.

Zeeuw, A. (1997). International trade in food and agricultural products. In K. Hathaway \& D. Hathaway (Eds.), Searching for Common Ground. European Union Enlargement and Agricultural Policy. (FAO Agricultural Policy and Economic Development Series - 1). Rome: Food and Agriculture Organization of the United Nations. Retrieved May 15, 2018, from http:// www.fao.org/docrep/w7440e/w7440e07.htm.

Assoc. Prof. Dr. Rita Remeikiene Lithuanian Institute of Agrarian Economics Lithuania rita.remeikiene@laei.It

Assoc. Prof. Zoltan Rozsa, PhD. School of Economics and Management in Public Administration in Bratislava Slovakia zoltan@rozsa.sk

Prof. Dr. Ligita Gaspareniene Lithuanian Institute of Agrarian Economics Lithuania ligita.gaspareniene@laei.It

doc. Ing. Jan Pěnčík, Ph.D. Brno University of Technology Czech Republic pencik.j@fce.vutbr.cz 


\title{
Abstract
}

\section{ASSESSMENT OF THE IMPACT OF THE INTERNATIONAL TRADE IN AGRICULTURAL PRODUCTS ON THE EU ECONOMIC GROWTH}

\author{
Rita Remeikiene, Zoltan Rozsa, Ligita Gaspareniene, Jan Pěnčík
}

Although international trade is an incontestable driver of economic development, scientific literature still lacks the studies to assess the impact of the international trade in agricultural products on the EU economic growth. The agricultural sector is treated as specific in comparison to other economic sectors as the EU subsidisation policies causes distorted competition in both local and global agricultural markets. The main purpose of this article is to assess the impact of the international trade in agricultural products on the economic growth of EU28. The results of the correlation and regression analyses have revealed that the international trade in agricultural products (in particular, section I and III products) contributes only insignificant part, to the economic growth of EU28 through the following indicators: GDP in market prices, self-employment, employment in the agricultural sector, labour force rate, subsidies and other transfers. The results have also disclosed that while analysing the impact of the international trade in agricultural products on economic growth, there is no necessity to research export and import volumes in separate as agricultural export and import show nearly the same (only with insignificant value differences) determinants of economic growth promotion. Another important conclusion is that the international trade in agricultural products mainly comprises the trade in live animals and animal products (meat and edible meat offal, fish and crustaceans, molluscs and other aquatic invertebrates, dairy produce, birds' eggs, natural honey, edible products of animal origin, not elsewhere specified or included, and products of animal origin, not elsewhere specified or included) as well as animal or vegetable fats and oils and their cleavage products, prepared edible fats, and animal or vegetable waxes.

Key Words: International trade in agricultural products, export, import, EU28, economic growth.

JEL Classification: Q17, F13, F63.

DOI: 10.15240/tul/001/2018-4-003 